\title{
Theatre Graphics and Graphic Theatre: \\ Zich's Semantics in Posters and Publicity
}

\author{
Martin Maryška
}

\begin{abstract}
The essay employs the concept of the 'semantic image' as articulated by Czech aesthetician Otakar Zich in his book The Aesthetics of Dramatic Art in order to outline how theatre publicity relates to theatre production and performance. Theatre graphics, posters, and other promotional materials contain images that substitute or compensate for what is not to be seen and heard onstage in form of 'technical images'; thus, these graphics condition the 'representational images' of dramatic locations. 'Publicity images can be also used to manipulate imagery associations related to actors as well as dramatic characters in order to facilitate their desired reception. This article focuses on the posters produced for Prague's National Theatre opera production of Tramvestie (2019) and two stagings of Peter Shaffer's Equus (1973, 2007) along with Alphonse Mucha's posters for Sarah Bernhardt.
\end{abstract}

\section{Key words}

theatre poster, theatre publicity, theatre iconography, visual communication, graphic design, Otakar Zich, Ivo Osolsobě, Gilbert Lesser, Uli Weber, Jakub Gulyás, Alphonse Mucha, Sarah Bernhardt

1 For the purpose of this article, I employ the following terminology. The term semantic image (in Czech, významová predstava) is used in order to avoid confusion with 'image' in sense of picture (graphics); the semantic image consists of the technical image (významová predstava technická) and the representational image (významová prédstava obrazová) (ZICH 1986: 43). 


\section{Introduction to 'yesterday's weather report'}

This paper employs the theoretical system developed by Czech aesthetician and theatrologist Otakar Zich to detect intermedial, cognitive and semiotic links between theatrical publicity, particularly posters, and theatre production and performance. Zich's essential ideas about theatre were outlined in his seminal book The Aesthetics of Dramatic Art (ZICH 1986, originally published in 1931) as well as in other works such as 'The Aesthetic Preparation of the Mind' (ZICH 1921).

Despite the fact that Zich's theories use the realistic theatre for the implicit material of his analysis (see OSOLSOBĚ 1981), Zich designs a prismatic framework through which also a non-representational theatre (especially after the so-called Second Theatrical Reform) can be understood and described (VELTRUSKÝ 1992). Zich's work in this area is often seen as pre-cognitive and pre-semiotic (for instance, VELTRUSKÝ 1992; OSOLSOBĚ 1981; HAVLÍČKOVÁ KYSOVÁ 2015), however later semiotic readings (SUS 1992, recently recapitulated by LÁNSKÁ 2016) and explanations in terms of communication theory (see OSOLSOBE 1992) and the aesthetics of reception take the audience into greater consideration (see OSOLSOBĚ 2007). All these frameworks can help make the scheme and especially Zich's concept of the 'semantic image'2 particularly applicable for research into theatrical publicity, despite the status of promotional materials, as a distinct media form.

Since for Zich a dramatic work or dramatic art is 'principal' or 'constructive' theoretical abstraction (OSOLSOBĚ 2007: 200), the theatre poster suggests such an abstract construction that becomes materialized and propagated as an individual playbill, poster, or publicity image in a specific context of visual and theatrical culture under certain social, economic, and commercial conditions. In line with this heterogeneity of modes and circumstances, several examples from various theatrical genres, practices, and epochs were chosen for analysis.

The semiotician, aesthetician and theatrologist Ivo Osolsobě, who acknowledged Zich's influence upon him, offers a 'cybernetic' definition of theatre that is a 'communication by means of communication about communication' (OSOLSOBĚ 2002: 90), a description mirroring Zich's triadic scheme actor actor figure dramatic persona, and that further extends Zich's original concept to non-representational forms of theatre. Within a model of theatre as a complex multimedium engaged in a hierarchy of communicative situations (OSOLSOBE 1992), a disponible para-theatrical or meta-theatrical circuit can be traced in the channelling of messages in the media of theatrical publicity, e.g. in terms of visual communication.

Quoting Ivo Osolsobě $(2002,2007)$, neither Zich’s Aesthetics nor a piece of theatrical ephemera is 'yesterday's weather report' (OSOLSOBĚ 2007: 190). That is Zich's work is useful not only to fill the 'referential gap' (BALME 1997) in tracing the theatre history, which the study of theatre iconography contributes to. The essay suggests that theatre publicity has also an epistemic value to theatre theory.

2 For a further discussion regarding various applications of Zich's concept of the semantic image, see (LÁNSKÁ 2016). 


\section{Spectacular and graphic}

In the introductory chapters of his Aesthetics, Zich principally opposes the prevalent contemporaneous stereotype circumscribing all theatre to the literary genre of 'drama'. In terms of the aesthetic experience, neither reading alone nor reading aloud is equal to spectating, thus dramatic art is defined as what a spectator sees and hears from the stage (ZICH 1986: 13). Yet, imagining while reading a story may entail visual and aural qualities: what a reader actually sees, such as typography or book layout, does not resemble (as an icon in terms of shape, material or function) anything that may be imagined in terms of meanings produced by these shapes (letters). For this reason, dramatic art requires its intrinsically ostensive or graphic ('názorný) manifestation on the stage.

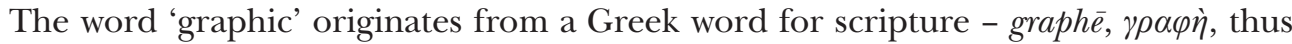
an utterance is made graphic by writing. Though translated from aural to visual form, it retains a symbolic coding. A written word is 'drawn' using a technique, thus graphics, or 'representation by means of lines' (LIDDELL, SCOTT and JONES 1996), and from the outset writing indicates drawing despite the later term suggesting iconic representation. In Zich's terms, the graphic stands for the iconic resemblance: the representational image is sensorially analogous or proportionate (visually or aurally) to the technical image. Further, a dramatic artwork is produced as a single unique performance, while a graphic artwork is reproduced in multitude. Graphics then is not graphic in Zich's meaning. Where Zich attains the visual metaphor of 'graphic' thinking, the complexity of the term 'názorný' is easier comprehensible for the English reader translated as 'iconic' or, in the theatrical context, 'ostensive'. This is why Osolsober instead proposed the word 'intuition' (OSOLSOBĚ 2007: 71), a meaning insinuated by a later remark by Zich (NOVÁK 1933) that can be read as: immediate insight or direct cognition that is not mediated by rational thinking in abstract concepts. ${ }^{3}$ Thanks to intuition ('graphic thinking') we do not need words to 'translate' artworks in order to comprehend them.

Inherent in dramatic theatre, a dramatic situation requires an ostensive, 'graphic' manifestation. ${ }^{4}$ This means an ostension or showing of people in their physical presence, i.e. in a dramatic or 'communicative situation' (OSOLSOBĚ 2007: 109), is a necessary and sufficient limit for graphic representation and sets up conditions for the scope and form of the graphic (ZICH 1986: 53).

3 Ivo Osolsobě explores the issue of translating the Czech word 'názor' and 'názorný' to English (OSOLSOBĚ 2007: 71). The Czech word NÁ-ZOR alongside the English IN-SIGHT, the German AN-SHAUUNG and the Latin IN-TUITIO denotes intuition, i.e. a form of knowing based on perception, not reason or proof. Osolsobě equates theatre, as playing and as language, to an epistemic model that a producer communicates to a receiver. Within this epistemic activity, this modelling balances the receiver's epistemic needs in more or less semantic correspondence to the surrogate original. Considering the pragmatic aspect of communication, being graphic or intuitive also indicates being instructive, or suitable for learning, a denotation that the word 'intuition' indeed later acquired, compare e.g.: tutor, tutorial ('intuition, n.' OED Online. Oxford University Press, March 2020. Web. 14. 03. 2020).

4 'Názorný vztah dramatických relaci pro určitou chvili, takto ohraničenou, nazveme dramatickou situací.' (ZICH 1986: 145) 
[...] we must always keep in mind that the dramatic action is presented or in other words, ostensive. Yet it is only an underlying material of the action, which is ostensive [graphic] and which we as the audience perceive: speeches, behaviour and actions of personas presented to us ostensibly [graphically] again through their physical appearance. Our own interpretation of this perception - the image - joins in, revealing the meanings and emotions of it all, thus disclosing an internal side of an external dramatic action. (ZICH 1986: 133)

Some limits for graphic manifestation can by implied from Aristotle: pathos, despite the essential effect of tragedy, is better not shown graphically by spectacle. 'A pathos is an act involving destruction or pain, for example deaths on stage and physical agonies and woundings and so on' (ARISTOTLE 105). A drastic action is not a dramatic action if the latter is understood as communication driven by an individual's intentions. The drastic ought to be shown by poetic means, dramatic plot or dramatic action, since 'to produce this effect via the spectacle has less to do with the art of tragedy and needs external aids' (ARISTOTLE 108).

Besides spectacle, I propose here that the 'external aids' can take the form of publicity or images in a poster. The question is then to what extent is the onstage graphic manifestation aesthetically justified, socially acceptable, or technically feasible. Certainly, as depictions of destruction, pain, death, agony, injury are often restrained and even kept off the stage, publicity conforms to community standards even more strongly, e.g. in terms of the principle of aesthetic (artistic) economy and the dramatic principle discussed by Zich in The Aesthetics as well (ZICH 1986).

Scenes that are too horrible to look at are also transferred into an imagined location (different times and environments are not equally delicate in this), and finally those actions that cannot be satisfactorily performed for technical reasons (for example, horse riding, etc.). (ZICH 1986: 180)

Since, unlike theatre performances, theatre posters are set in a public forum and thus are accountable to different social norms, a publicity text must generally refrain, for example, from graphic nudity. Clearly displaying human private parts is indeed the most graphic for theatre and too graphic for publicity (or both). The example illustrates the multiple meaning of the word with which I play here as a sort of rhetorical trope.

5 'Obrátíme-li se ted' $k$ rozboru dramatického děje a především $k$ psychologické analýze lidského jednáni jako jeho základu, musíme být stále pamětlivi toho, že jde o dramatický děj předváděný, tedy názorný. Názorný je ovšem jen jeho podklad, námi jako diváky vnímaný: mluva, chováni a činy, daných nám taktéž názorně svým tělesným zjevem. K tomu se pridružuje naše vlastní, interpretace tohoto vněmu, obrazová představa, jež nám odkrývá myšlenkový i citový význam toho všeho, odhalujic nám tak niternou stránku vnějšího dramatického dění.' (ZICH 1986: 133)

6 'Za scénu, do myšleného mista děje, prèkládaji se také výjevy, jež by byly př́liš hruizné hrüzné na pohled (ruizné doby a rüiná prostředi nejsou v tom ovšem stejně jemnocitná, a konečně ty akce, jichž nelze z di̛vodů technických uspokojivě provést (napr. príjezd na koni apod.).' (ZICH 1986: 180) 'It is known that evil, horrible, even repulsive actions or appearances can be described, after all, but how unbearable it is to see and hear them from the stage. (...) Still, they are demanded at times, and there are audiences who are hungry for such gross sensations (...).' (ZICH 1986: 159) 'Je známo, že děje nebo zjevy ošklivé, hrůzné, ba odporné daji se koneckonců popisovati, ale jak nesnesitelné, jest, viděti a slyšeti je s jeviště. (...) Jsou doby, jež si žádaji, a jsou vrstvy obecenstva, jež jsou lačny takovýchto hrubých sensací (...).' (ZICH 1986: 159) 
Therefore I assume that graphic stands: (1) for ostensive, visible, performed, or intuitive, as in Zich; (2) for drastic and obscene, as in e.g. media's graphic content policies; and (3) for the written, drawn and reproduced, as in 'graphic design'.?

Not being the work of the poet, spectacle, though attractive (as Aristotle himself notes), demands the lowest graphic manifestation, so to say the lowest possible degree of ostensiveness. Pictorial-art, like set design, may undermine the dramatic effect (ZICH 1986: 31). Spectacularity contrasts with corporeality, i.e. anything that is not corporeal and thus cannot be shown purely ostensively (such as a human body or a thing, cf. Zich's postulate of materiality of scenic objects - ZICH 1986: 185) or, in other words, anything conceived as unreal counts for spectacular illusion of which a spectator is aware, and its reception, either positive or negative, is conditioned by theatrical framing, stylisation, and conventions. Further, there are indeed technical restrictions for persuasive graphic manifestation, as Zich points out.

As neither spectacular nor graphic content can ever be graphic enough to gratify spectators' scopophilia, Aristotle's advice is to keep it on stage but expressed by artistic language. According to Zich (seconded by Osolsobě), language is as inherent to theatre as speaking is for humans (OSOLSOBĚ 2007: 129). Language is present, bare (as is) on stage - simply, as language - that is ultimately ostensively, i.e. graphically. Language can also become 'unbearably' graphic when it 'makes something public that cannot bear being public' (ZICH 1986: 159). ${ }^{8}$

This essay suggests and will illustrate that publicity graphics may compensate, amplify, or substitute for the spectacular. Despite its inherent and limited means for representing reality, theatre may try to mediate reality by illusion as in spectacle and naturalist theatre, by the use of film projection as in intermedial theatre, or by keeping the graphic or spectacular off the stage but within the context of theatrical communication as a poster image or publicity text.

\section{Offstaging the offstage}

In 2019, Prague's National Theatre produced Tramvestie ${ }^{9}$ in a production promoted as a video opera. Petr Wejsar composed music to Pavel Novotnýs poetry that attempts to capture the poet's impressions based on real-life recordings of passengers' conversations on a tram ride. The sober stage design solely features four typical red tram seats occupied by singers/actors representing public transportation passengers whose visual characterization is further detailed by rather realistic costume design (see Fig. 1).

$7 \quad$ For detailed word reference see: 'graphic, adj. and n.' OED Online. Oxford University Press, March 2020. Web. 14. 03. 2020. In 2002, the Oxford English Dictionary extended the meaning of the word graphic for 'Providing or conveying full, unexpurgated detail; expressly stated or represented; explicit, esp. in the depiction of sex or violence'. The dictionary traces the history of the word in meaning to the second half of the nineteenth century.

8 'zveřejněni toho "co zveřejněni nesnese”" (ZICH 1986: 159). The Oxford English Dictionary also refers to graphic speech with the meaning of vulgar language. OED Online. Oxford University Press, March 2020. Web. 14. 03. 2020.

$9 \quad$ Premiered on 17 April 2019 at the New Stage, National Theatre, Prague. 


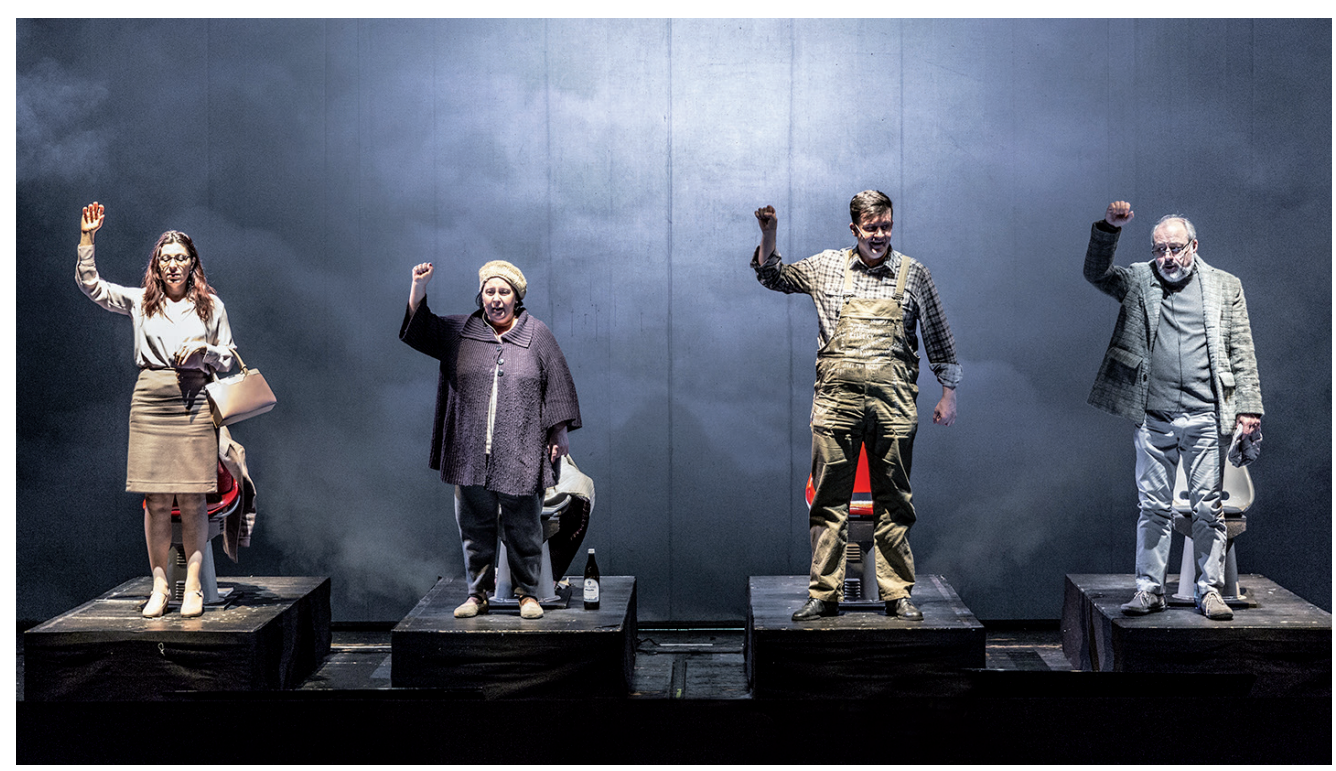

Fig. 1: National Theatre (Prague), Tramvestie. Photo by Patrik Borecký, 2019.

Even if a stage is empty of decoration and filled only with the presence of acting actors, it is always minimally graphic since the action must happen 'somewhere'. Zich comments on this representation: 'Usually, the place requires more determination' (ZICH 1986: 179). ${ }^{10}$ The poster image by Bratislava-based visual artist Jakub Gulyás features a realistic photographic image of an actual tram, an image which is also reproduced on the cover of the theatrical program (see Fig. 2, 3). Since within the scenography the place (the tram) is determined only metonymically with the tram seats, the poster and programme are used to graphically specify the setting.

The Tramvestie poster suggests the dramatic space yet does not show the location itself but the exterior image of the tram. Stage screen projections functioning as the view from the tram's window of the exterior showing the passing landscape also augment the dramatic space, while this technique respects the spatial unity in the same fashion as do dramatic locations that are not manifested graphically but only 'thought' or suggested, such as a half-opened door into another room (ZICH 1986: 180). However, the publicity graphics made graphic what is not possible onstage, since a particular action cannot take place inside and outside in the same moment. A spectator is provided with simultaneous images of both.

Unlike mid-nineteenth-century pictorial posters promoting spectacular theatre, a genre which will be referred to below, Gulyás's publicity image does not amplify the visual sensation of the stage, but rather complements and substitutes for it. For the actor, being a real, living human 'all other compounds seem to be less real' (PROCHÁZ- 


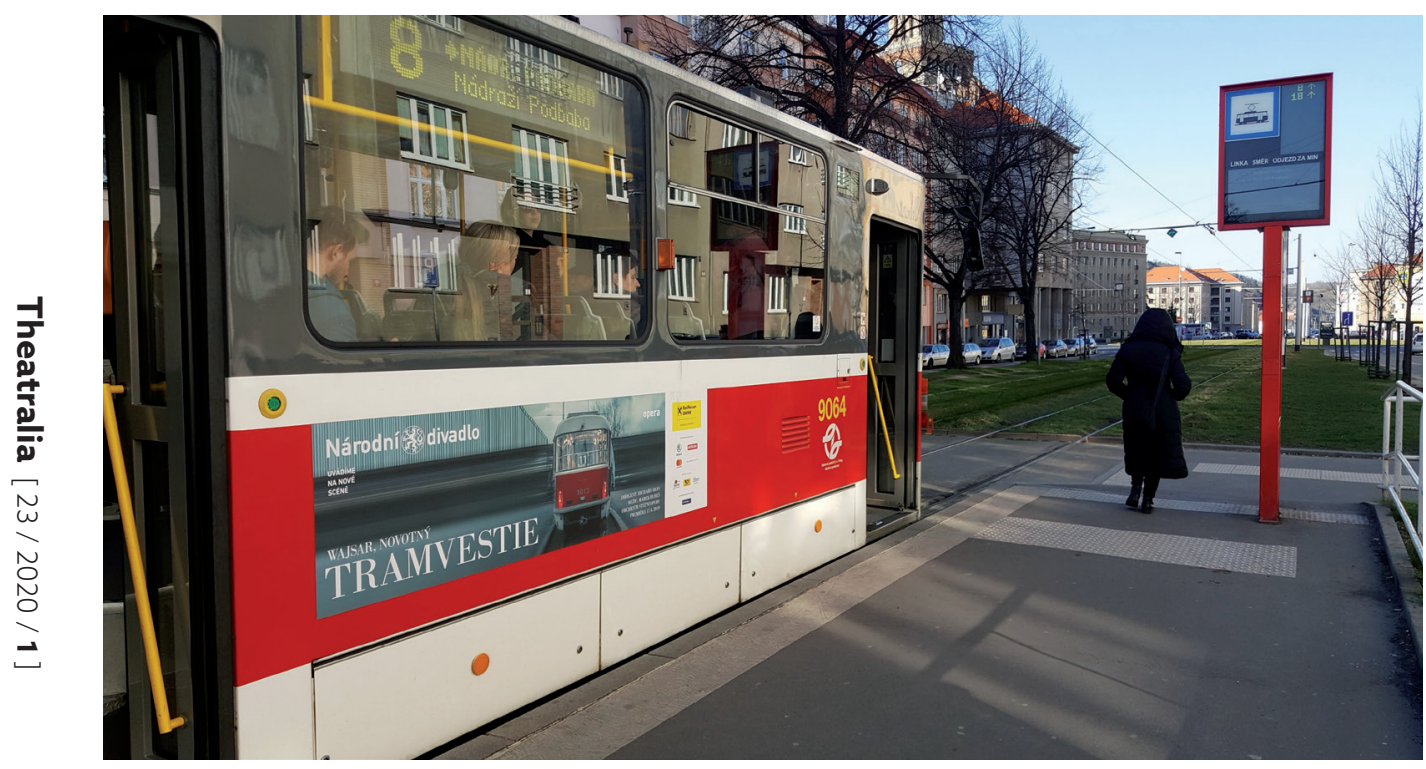

Fig. 2: National Theatre (Prague), Tramvestie. Featured publicity photography by Jakub Gulyás, graphic design by Petr Huml, 2019. National Theatre Archive.

KA 1994: 7). ${ }^{11}$ In the stage production, only actors dressed in costumes, an extension of actors' corporeal self (ZICH 1986: 109), were on the stage. Any other props, seemingly less real, were set aside: even stage video projection to illustrate reality. On the contrary, a photographic image and graphic art mechanically or digitally reproduced the real world.

Additionally, Tramvestie was preceded by a paratheatrical event: a ride in a real historic tram down Prague's streets. Together with this real-life location, the actual stage performance with the poster and the programme may be assembled in the spectator's mind into a coherent semantic image, a mental representation of the event. ${ }^{12}$ This construal can be shaped by means of specific semiotic coding that depends on media, and can entail specific cognitive processing requirements to provide a certain aesthetic experience. Within theatre reception studies, this cognitive construal may then be discussed, for instance, from a poetics perspective as a multimedial conceptual artwork, or from an aesthetics point of view as the actual aesthetic experience, i.e. a mental representation in a spectator's mind. 'Media images in particular are characterized by the simultaneity of event, image and perception' (BACHMANN-MEDICK 2006: 262),

11 'Dưvod, proč se vše toči kolem herce, je, že je to skutečný, živý člověk. (...) Herectvi se vyznačuje tím, že umělec je osobně přitomen ve svém výtvoru. Všechny dalši složky se proto jeví jako méně reálné.' (PROCHÁZKA 1994: 7)

12 Recalling Lakoff and Johnson's concept of embodied realism (LAKOFF and JOHNSON 1999), cognitive theatrologist Bruce McConachie describes how the theatrical experience is determined by 'interaction in the material world of performance' (MCCONACHIE 2001). Cognitive psychology extending the early theory of John Dewey on aesthetic experience (DEWEY 1934) can be seen to support the presented hypothesis. 


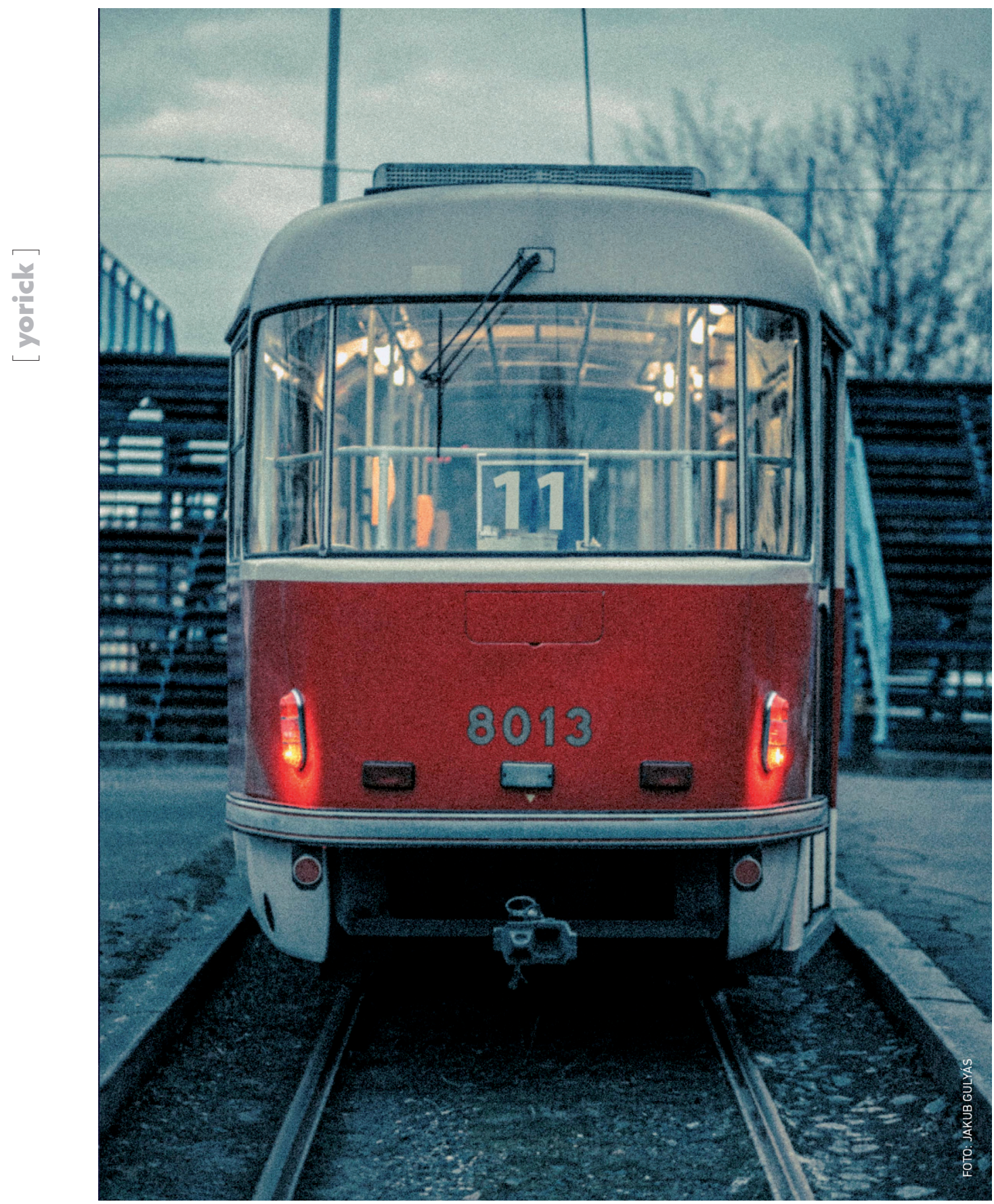

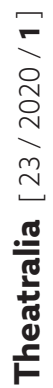

Fig. 3: National Theatre (Prague), Tramvestie.

Publicity photography by Jakub Gulyás, 2019. National Theatre Archive. 
and media images can be assumed to have trained contemporary spectatorship for such simultaneity.

\section{Constructing a 'God from the poster'}

In 'The Aesthetic Preparation of the Mind' (ZICH 1921) and later in The Aesthetics of Dramatic Art (ZICH 1986, originally published in 1931), Zich introduces and develops the idea of the 'semantic image' (významová představa) in discussions of how representations of dramatic characters (personas) and places are created.

Zich's semantic image consists of two types: the 'technical image' (významová představa technická) emerges from the perception of the stage in a spectator's mind, which in turn induces a 'representational image' (významová představa obrazová; alternately translated as referential or symbolic) as subjective mental content. An acting actor renders such a technical image, whereas a dramatic persona is a related representational image. These representations are not objective entities, but subjective mental representations in the mind of the spectator. In the same manner, for the viewers in their cognition a stage decoration technically represents a dramatic location of a dramatic action.

In order to integrate theatre publicity as well as non-representational theatre (and publicity for non-representational theatre), I propose to extend the concept of the representational image. It is the target signifie and the psychological content that is processed in the mind through images, but also as concepts (THAGARD 2005) - a process which has gestalt qualities. The work of the theatre practitioner is to generate technical images via diverse media, and to arrange them in a way to evoke the most persuasive and coherent representational image.

This brief and simplified explanation suffices to present the key proposition that theatrical publicity, functioning as an associative semantic image, participates in inducing representational images of characters (personas) and places. In the final chapter of The Aesthetics of Dramatic Art, Zich mentions indirectly what kind of a pictorial representation can be evoked from spectator's memory while watching a show:

By means of their resemblance, the perceptions provided by a scene evoke mental images that we acquired by outer experience (i.e. from 'reality') and we compare them with the percepts. [...] Accordingly, a water goblin on a stage can evoke a memory of a similar water goblin, for example painted by Schwaiger. (ZICH 1986: 282) $)^{13}$

In line with Zich's view, poster or publicity images to which the spectators are exposed beforehand can manipulate what they cognize when watching a show, or at least what was intended to register in the mind.

13 '(...) vjemy, jež nám scéna poskytuje, vyvolávaji v nás svou podobnosti představy, jež máme ze své vnějši zkušenosti (tedy ze „skutečnosti”) a my je s nimi srovnáváme. Ale jen co do podoby, ne co do skutečnosti - to je rozdil. Stejně v nás může např. vystoupivši vodník vyvolat vzpominku na podobného mu vodnika někým (třeba Schwaigrem) namalovaného.' (ZICH 1987: 282) 
To exemplify how posters function as associative semantic images, I would like to discuss the case of publicity images for two productions of seminal Peter Shaffer's Equus. The 1973 play dramatizes a story of Martin Dysart, a child psychiatrist treating teenager Alan Strang and searching for the reasons the boy blinded several horses. In a book edition following John Dexter's premiere staging ${ }^{14}$, the playwright instructs directors:

Any literalism which could suggest the cosy familiarity of domestic animal - or worse, a pantomime horse - should be avoided. [...] Great care must also be taken that the masks are put on before the audience with very precise timing - the actors watching each other, so that the masking has an exact and ceremonial effect. (SHAFFER 1974: 17)

Practically, Shaffer warns against anything too literal or iconic in the stage production, yet a real animal appears in Uli Weber's publicity photograph. The publicity image for a 2007 revival directed by Thea Sharrock in West End's Gielgud Theatre ${ }^{15}$ features Daniel Radcliffe posing next to an actual white horse, suggesting what a spectator is supposed to see, thus complementing the semantic image of a horse. A living animal would be too 'naked' on the stage, an actor's full frontal nudity would be too 'naked' in the publicity (or, as we have argued above, too graphic). For example, having a real horse on stage was the main attraction to 1909 London sensational spectacle For Wife and Kingdom by Ward Bailey. This production teased the London audiences by a promise of a horse-drawn sleigh under the attack of wolves in a snowstorm (see Fig. 4):

The advertisement boasted of a real horse, but not of course of real wolves. The poster depicted not what the audience would see but what it was supposed to think it saw. That is how posters which depicted the most sensational scenes in popular should be read. They reproduced the most effective possible version of the action, which might or might not be realized in full on stage, and theatregoers seemed happy to accept them in that spirit. (DIAMOND 2012: 61)

Unlike Bailey's, Shaffer's play challenges directors with staging an image that should both be aesthetically persuasive as a real stallion called Nugget and a divine being Equus, in both cases establishing a meaningful gestalt. Despite the fact that a horse is played by a masked actor or chorus, a series of technical images combine with two representational images: one for the horse Nugget, another for the deity Equus. What is actually staged as Equus (and Equus) are Alan Strang's memories and visions. Such representations demand graphic spectacle or storytelling and may erode the dramatic principle in the strict meaning intended by Zich. ${ }^{16}$

14 Opened 26 July 1973 at the Old Vic Theatre, National Theatre, London.

15 Premiered on 27 February 2007 at the Gielgud Theatre, London.

16 'The more poetic a dramatic text is, the more one can expect that dramatic effect would be weakened. (Čím je text dramatického díla poetičtě̉š́i, tím spiše lze očekávati, že bude dramatičnost díla (t. j. představení!) zeslabena.)' (ZICH 1986: 30). If they serve the dramatic plot, poetic forms such as lyric monologues, epic storytelling exposing parallel plots, and speeches presenting ideas are not in contradiction to the dramatic effect and 


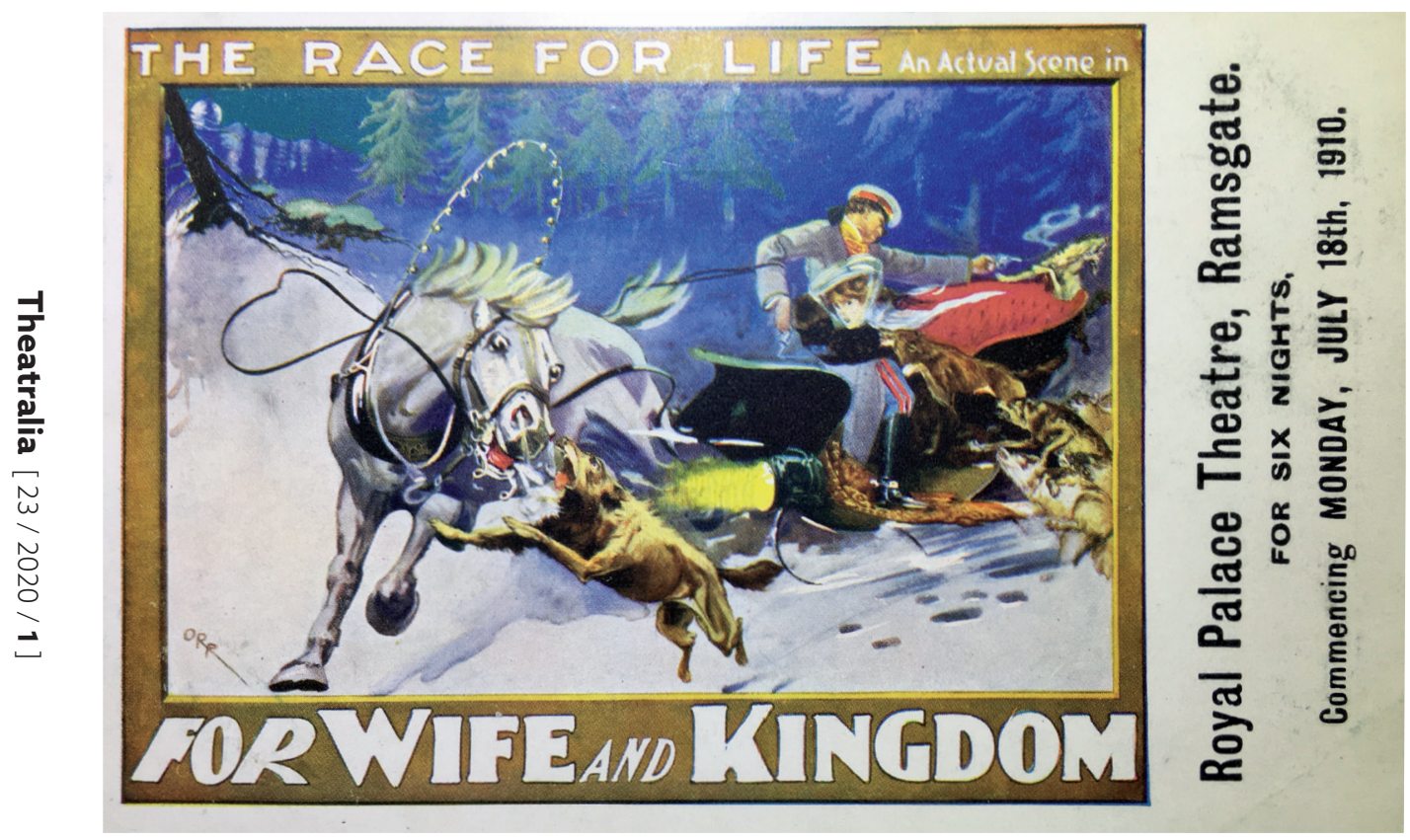

Fig. 4: Royal Palace Theatre (London), For Wife and Kingdom.

Postcard, anonymous, 1910. Michael Diamond Collection.

The poster by Ken Briggs for the 1973 The National Theatre production of the same play features a graphic of a horse by Gilbert Lesser (see Fig. 5). It is an image of a horse - schematic, geometric towards abstraction, reminding of a ceremonial mask, 'a mask of horsedom' (SHAFFER 1974: 10). ${ }^{17}$ Artistic stylization renders meanings, for the poster conceivably reminds the viewer of primitive art, thus foregrounding an idea - a concept rather than an image of Equus the God. Hyperbolically expressed, deus ex machina, understood here as an effect such as a spectacle (or an element of storytelling), which corrupts dramatic effect, cannot function in an actual dramatic plot but could be placed off the stage as a 'God from the poster' or 'deus ex machina polygrafica'.

Uli Weber's realistic photography supplied an ostensible idea, a visual support to evocation of the semantic image of Nugget the horse, which was ostensible - that is, based on iconic resemblance. Gilbert Lesser's graphics expanded the semantic image with additional symbolic meaning. A juxtaposition of the two publicity images of Equus illustrates how Zich's concept of the semantic image combines semantics with psychology. Shaffer's play thematizes intricacies of the human mind and how it assembles various

principle. (ZICH 1986: 86) In this case a playwright is fully justified to use, for example, monologues to manifest the mental condition of dramatic personae if it cannot be manifested in conversation ('Odtud plyne pro dramatika plné právo, aby užil monologu tak, kde jisté duševni stavy dramatické osoby musí být (ale jen z těch!) zveřejněny a nemohou býti jinak, na př. v rozmluvě osoby se suým spojencem)' (ZICH 1986: 156).

17 The art direction and graphic design is attributed to Ken Brrigs (POYNOR 2017). The stage and mask design is the work of John Napier. 


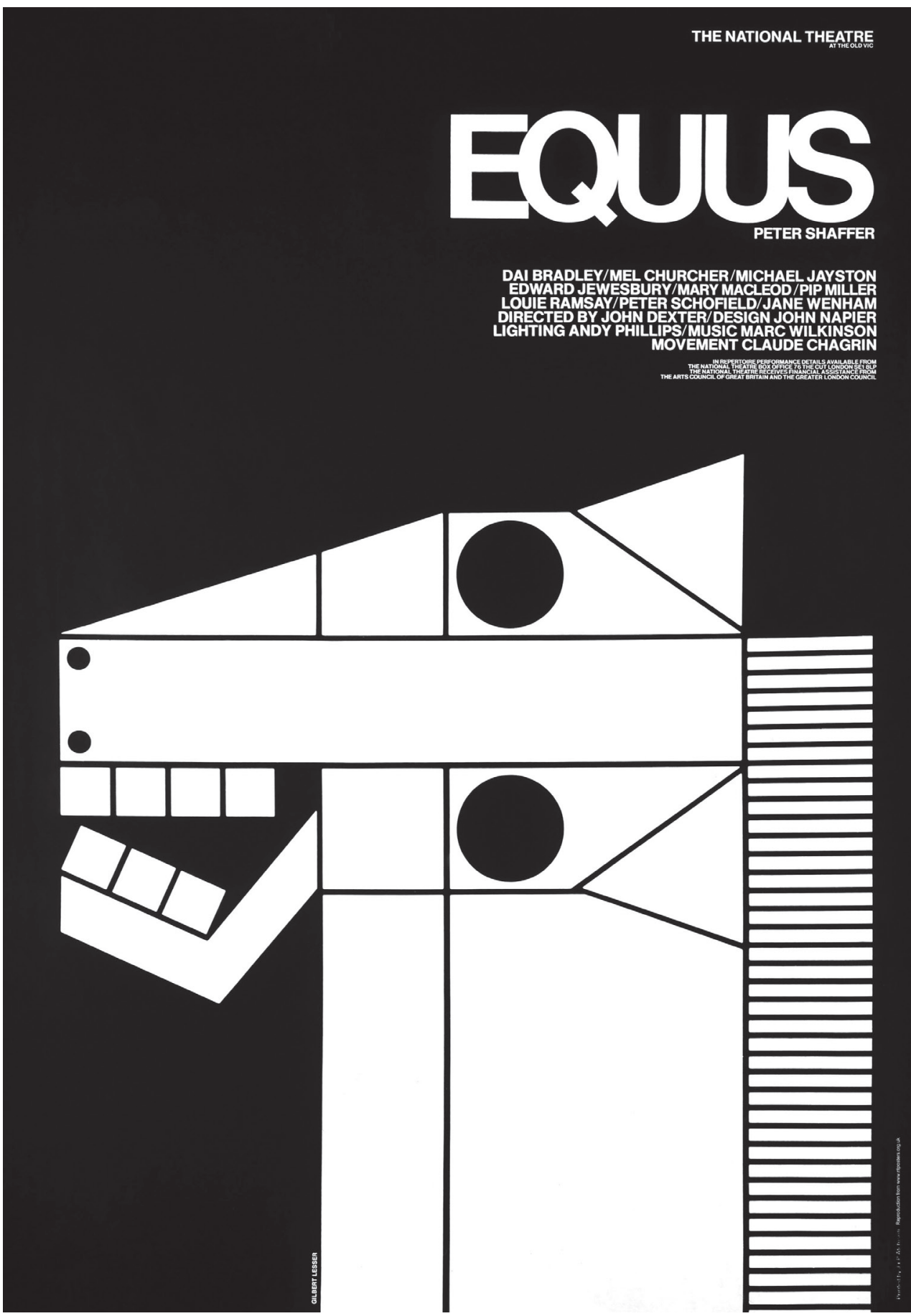

Fig. 5: National Theatre (London), Equus. Poster art by Gilbert Lesser, graphic design by Ken Briggs, 1973. National Theatre Archive. 
pieces of information 'acquired from our external experience' (ZICH 1986: 93), which may be of iconic, symbolic, and internal haptic nature. A reproduction of 'Our Lord on His way to Calvary' that he could see while his mother was reading the Bible out loud to him, television western films, stories about horses, and an early memory of riding on a horseback blended with images of fear and desire from 'inner experience' (ZICH 1986: 93) eventually make the foundation of Alan Strang's belief in a horse-god. The image of Equus takes the place of the picture of Christ on the wall of his room:

'But he recovered when he was given the photography of the horse in its place?'

'Then suddenly he knelt down.'

'In front of the photograph?' (SHAFFER 1974: 58)

The image that Alan adores might be seen in Lesser's graphics - 'God from the poster,' deus ex tabula graphica. Alan's father 'happened to be a printer' (SHAFFER 1974: 107). The image of a horse might be one of the posters printed by Alan's father. Images, especially in the contemporary scopophilic and visual culture, hold a divine power of idols over the semantic image of the world perceived through the sense of vision, as Mitchell elaborates (MITCHELL 2015).

Contemporary cognitive psychology discusses the representational character of images: 'Mental images should therefore not be understood as representations of the external world. Rather, the external world should be seen as a mere projection of our internal images' (BACHMANN-MEDICK 2006: 262). The semantic image could be then conceived as constructional (as opposed to representational), and as such projected back onto the external world of the stage. The effect is known as the visual projection phenomenon: 'The outside projection of a mental image could be considered similar to the projection of a film on a screen: the brain is the generator of the images sent to the outside world' (RUGGIERI 2017: 969). Such an understanding problematizes and sheds new light on the mutual relations between percepts, technical images and representational images, in Zich's terminology. ${ }^{18}$ The constructional nature of the mind allows visualizing a deity in (or through) a horse, as well as seeing a dramatic persona in (or through) an actor.

18 Contemporary cognitive studies support the plausibility of Zich's interpretation: 'The visual perception and the visual images coexist. While a person perceives the external environment can simultaneously develop visually other images' (RUGGIERI 2017: 973). Ruggieri continues: 'The mental visual images actually perceived, as well as the recalled images of previous visual perceptions and the new images of pure imagery activity, interact each other and with other modes of perception (trans modal perception). They are the basis of cognitive activities, under the transformative processes of brains (abstraction, etc.)' (RUGGIERI 2017: 971). 


\section{'Name' for an image: ut theatrum pictura graphica}

Both the poster and theatre may be conceived as an interplay between image and text, the plexus of which was subject to change over two centuries: the Gutenberg Galaxy morphed into the Electric Age, in McLuhan's terms (MCLUHAN 1969), along with scopic regimes (METZ 1982), spectatorship, images schemas (MCCONACHIE 2001), media, artistic sensitivity and imagination. A word once written down thus merged with the visual world and became typography (ONG 1994). With posters, typography merged directly with images, and finally when a pictorial poster was posted, a word returned back to the objectual world.

We live in a described and 'tagged' world, and everything, we read (or whenever we can read) can be rendered verbally. We have descriptors or 'name tags' not only attached to real things, but also regarding things that are represented by other things (images, signs, models) or represented in our imagination. (OSOLSOBĚ 2007: 181) 19 $^{19}$

Referring to 'name tags' or 'descriptors' (nápisy), Osolsobě offers an explanation of how thinking works as a process of 'coming into consciousness', 'realizing' something (uvědomováni si). Thinking occurs when a percept is linked with a concept deposited in one's personal lexicon (OSOLSOBĚ 2007: 180). Osolsobě treats Zich's 'semantic image' as some sort of a descriptor, a name tag. The assumption stems from Zich's remark: 'Every relatively stable percept is drawn out from our experience on the basis of resemblance to an image by answering the most general question: what is it we see or hear; and for this reason it may be called a semantic image (...)' (ZICH 1986: 42 in OSOLSOBĚ 2007: 182). ${ }^{20}$

Osolsobě's account contributes to understanding how 'theatrical thinking' may work, or how the verbal (textual) conditions the imaginative (visual). Zich's term 'image' (predstava) is representational, literally similar to 'pictorial' (zobrazujici, obrazová), which might imply unreliable reading. According to Zich, a spectator cognizes ('theatrical thinking') a theatre performance via visual images. This thinking is often reduced to visual imagination as a prevalent mental faculty of processing the perception of the stage, a presence enriched with remembered and fantastic images. The idea of human thinking in images was refuted in Vygotsky's Psychology of Art (VYGOTSKY 1971) as well as in Gombrich's Art and Illusion (GOMBRICH 1961). In fact, Gombrich affirms that one's visual perception is determined by conceptual pre-understanding, or, so to say, imaginative seeing is formed by conceptual pre-understanding.

19 'Žijeme v popsaném světě a na všem čteme (nebo kdykoli mưžeme číst) verbální responzi. Máme 'nápisy' nejen na věcech skutečných, ale $i$ na věcech představovaných jinými věcmi jinými věcmi (obrazy, znaky, modely) či představovaných v naši představivosti.' (OSOLSOBĚ 2007: 181)

20 'Každý náš poměrně stálý vněm vybavuje v naši zkušenosti na základě podobnosti nějakou prédstavu odpovídajicí na nejušeobecnějši otázku, co to jest, co vidime, slyšime atd., pročež ji nazveme představou významovou (...).' (ZICH 1986: 42) 
Theatre posters indeed function as descriptors and, despite their pictorial qualities, should be first read literally in terms of the title of the production. Until the second half of the nineteenth century when the pictorial poster prevailed, theatrical events had been announced foremostly by textual playbills that allured audiences with refined poetic wording (SENELICK 2018: 173). In line with Osolsobě, such playbills extended the spectator's vocabulary with a multitude of new 'name tags,' or drew a conglomeration of 'labels' or 'descriptors' out of the passive vocabulary. 'Read beforehand, such descriptions $[\ldots]$ have the effect of preconditioning the audience actually to see the things [...]; the synopsis makes the action clear and helps to make settings magnificent' (BRATTON 2003: 58 in SMYTH 2010: 8).

In fact, Equus is such a 'name tag' that at first glance depicts an image of a horse displayed on a poster. This is the very first percept rendering both a technical image as well as the initial representational image. It is also a ready-to-use label for all the related perceptual information in the actual performance. The spectators may liken it to Alan Strang when he first comes across the name 'Equus'. This is the moment when the 'semantic image' of the deity gains coherence and (semantic) meaning, while on stage the character starts to see his god in a horse. 'Name tag' of dramatic personae featured in theatrical programmes may work in a similar fashion.

From a strictly epistemological point of view, such a 'person' - whether from real life or from a play - is something that we add to an optical and acoustic stimulus; it is a mere image that we place under (hypostasise) the sensory stimulus (percept) as a constant and unchanging substance. We are compelled to the image by the very fact that the perception remains at least partly the same. Said image fuses with this perception and so gains an ostensive (graphic) quality. As the character of the drama only exists in our mind, albeit on the basis of a perception, we need constant markers to be able to speak - or even think - about it; the preferred method (just as in life) is to give it a name tag. 'The lists of dramatis personae' prevalent in play scripts are evidence of this. (ZICH 1986: 36) ${ }^{21}$

While watching a production, a spectator's mind does not directly and continuously project from the memory visual images onto a stage by recalling particular images, for example, from posters. Instead, when a percept is recognised as something resembling something else, the mind labels it with a 'name tag' - such as (supposedly) a horse, a psychiatrist's room, a stable, a tram - almost as in the case of the Elizabethan Theatre, where locations were indicated by means of such tags. The attribution is carried throughout the performance and suffices for a persuasive aesthetic experience if not hindered by anything that brings forth doubt in the acquired comprehension.

21 'Př́sně noeticky vzato, je takováto "osoba”, at’ ze života nebo z divadelní hry, něco námi přimyšleného k zjevu optickému a akustickému; je to pouhá představa, již $k$ tomu zjevu (vněmu) pokládáme (hypostasujeme) jako stálou a trvalou jeho podstatu (substanci). Pohnutkou $k$ tomu je nám právě to, že tento vnímaný zjev zůstává aspoň částečně stejný. Splývajic ovšem s tímto vněmem, prijímá od něho jmenovaná představa ráz názornosti. Ježto je tedy dramatická osoba jen myšlená, byt’ na podkladě vněmu, potrebujeme nějaké stálé značky, abychom o ni mohli myslit, po př́padě i mluvit; nejraději si vypomáháme (tak jako v životě) jejim pojmenováním. O tom svědč "seznam dramatických osob", u dramat obvykly.' (ZICH 1986: 36) 
A promotional text is derived from the show in a process which takes an ekphratic position to theatre. Under conditions when a textual annotation precedes the theatrical event, the vector changes. According to Mitchell's contemplations on Ut pictura poesis (MITCHELL 1994), ekphrasis is a matter of otherness and models a relation between the primary and the secondary. An understanding of what is derived from what, what is conditioned by what, what is primary and secondary, etc., all relate poster aesthetics to design practices, theatre aesthetics and production through the interplay between knowing and seeing. In addition, Zich, in search of the quintessence of theatre, hypothesizes that the quality of the 'other' image and text require specific conditions, and thus Zich reassesses the aesthetic essentials of theatre as spectacle and as literature. ${ }^{22}$

\section{Semantic image sacré}

Attending the theatre, we meet a multitude of [...] unreal, just artificially created 'persona'. During out visit, we have actually a triple grouping: a perception of the stage, an associated image of an acting actor (for example, Vojan), along with an associated image of someone a persona (for example, Cyrano). The image of the actor could be very clear if we know him well from elsewhere, or unclear if the actor is just 'some' actor not known to us otherwise. (ZICH 1921: 199 $)^{23}$

Theatrical publicity is also intended to enrich or manipulate 'semantic images' by preparing a spectator to accept that a certain role is cast with a certain actor, the choice of which undermines casting stereotypes attached to them. Daniel Radcliffe was separated, literally dressed down from the Harry Potter character, and positioning his figure next to a horse introduced him as Alan Strang from Equus. In a similar stance, Sean Mathias' 2013 Broadway production of Breakfast at Tiffany's cast the English actress Emilia Clarke. Subsequently, the publicity for the production involved a photograph of Clarke (see Fig. 6) to let 'everybody know that she had it' (HODGES and SEDARIS 2016: 196) and thus loosen the ties between the main character and the actress Audrey Hepburn, the star of the iconic 1961 Hollywood film adaptation. A set of impressive

22 For example, Zich subordinates the literary drama (textual) to a stage performance (visual) and postulates the totality of actor's performance (they must be audible by speaking, and visible by stage appearance). The problem of seeing and knowing can be set up as relation between the psychological and semantic (SUS 1992). In commentaries to the 1986 edition of Aesthetics, Osolsobě questions Zich's idea that a semantic image of an actor is not graphic. Zich claims a spectator knows who a certain actor on the stage is. The notion does not come from seeing but from knowing (ZICH 1986: 340). The onstage talking, of course, participates in inducing representational images of characters (ZICH 1986: 156).

23 'Navštěvujice divadla, seznámíme se tak s velkým množstvím takovýchto neskutečných, jen uměle vytvořených "osob". Při každé z nich máme vlastně trojitou sdruženinu: vjem, který jsme z jeviště měli, $k$ němu asociovanou predstavu hrajicicho herce (na př. Vojana) a taktéž přidruženou predstavu jakési osobnosti (na př. Cyrana). Představa herce může býti velmi zretelná, znám-li jej na př. velmi dobře odjinud, nebo jen nezřetelná, je-li to pouze "nějaký” herec, jinak mně neznámý.' (ZICH 1921: 199) 


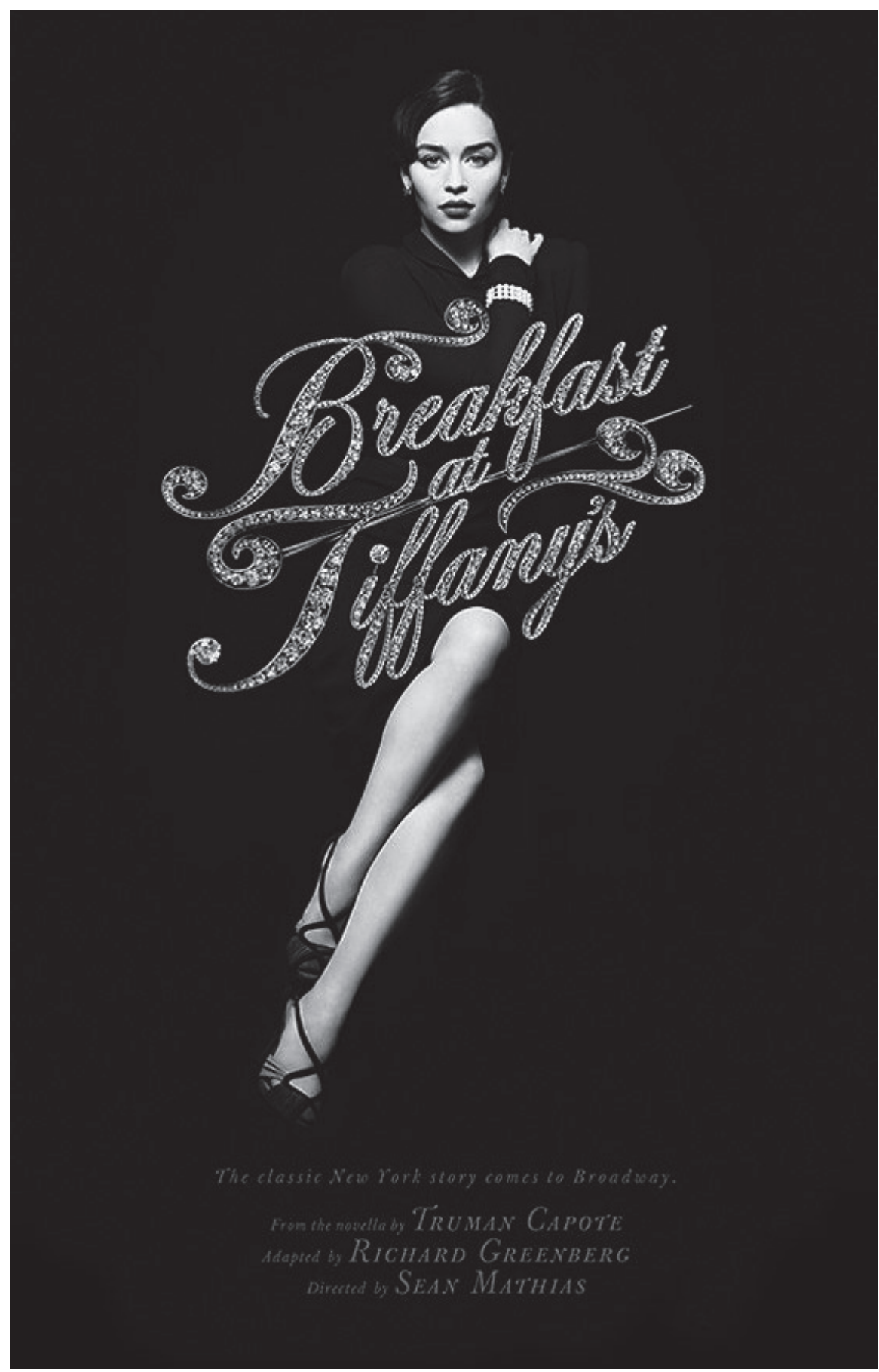

Fig. 6: Cort Theatre (New York), Breakfast at Tiffany's. Art direction by Drew Hodges, Vinny Sainato, Darren Cox, logo design by Dan Forkin, photography by Jason Bell, 2013. SpotCo. 
publicity images for the 2013 production was designed to make a firm connection between the character of Holly Golightly and Clarke.

SpotCo artistic director Drew Hodges, who was responsible for the poster, indicates: 'It was decided that we have to support our leading lady by letting everybody know that she had it by photography' (HODGES and SEDARIS 2016: 196). Clarke just needed that support not to be seen as a mere Hepburn's replacement or 'understudy'. A new set of images was required to help the spectator associate Clarke with Holly Golightly and loosen an association between an image of a dramatic persona and the image of Audrey Hepburn.

If Clarke was used in the publicity to break the associations with the actresses who had previously performed the same role, Sarah Bernhardt used posters for making certain roles associated with her alone. Sarah Bernhardt was certainly not just 'some' actor, and her image was well-known among the public at the turn of the twentieth century, a persona made even more prominent by means of publicity - 'the places we know her from' recalling Zich's quote. For example, in the posters of Alphonse Mucha (also a stage designer for many shows) Bernhardt sought to appear and be thought of as taller than she was in real life. Interestingly, she might have really succeeded in conveying that impression when a poster image became blended with the memories of an admirer of Bernhardt and connoisseur of Mucha posters who kept the poster hanging in his living room. ${ }^{24}$ In the poster for Hamlet (see Fig. 7), Bernhardt appears taller in figure proportions compared to the documenting photograph (see Fig. 8).

Appearing on a poster as a youthful man, the actress was also preparing the audience to accept a woman cast in a male role. ${ }^{25}$ At the end of the nineteenth century, French and English audiences were accustomed to the so-called 'breeches roles' or girl boys (CORBIN 2012). Breeches were tight-fitting pants in which actresses usually appeared

24 Marcel Proust was one of Bernhardt's admirers. She inspired the character of the actress La Berma in the second volume of the cycle In Search of Lost Time: In the Shadow of Young Girls in Flower (À la recherche du temps perdu: À l'ombre des jeunes filles en fleurs, 1919). The narrator recalls memories of theatre performances of La Berma and contemplates that images and thoughts (namely of an ancient statue) could have eventually 'beautified' Berma's acting.

25 Cognitive theatrologist Bruce McConachie introduces the concept of identity and 'conceptual blending' (MCCONACHIE 2011). With the stage figure in Zich's terms, a new 'actor/character' emerges as a conceptual blend of the identities of an actor and all features associated with a dramatic persona. The conceptual blend is possible because of what Zich calls 'theatrical conception' (ZICH 1921), which allows a 'double scope', to use McConachie's term. The double interpretation of a percept, Zich suggests, is possible because a spectator assembles two distinct, but not contradictory images and concepts. The spectator compares two images (the first is perceptual, technical; the second a conceptual, representational image), but not in contradictory terms of their realness, but their resemblance. Therefore, an actor is to a dramatic persona like a statue to a man: "when I see a statue, I assume "It is some statue" and "It is some man", because these notions are not from the same category of actually existing things. "Some man" belongs to the category of things that exist only ideally - in my mind. [...] Therefore I can say also in dramatic art: it is an actor A and at the same time King Lear [...]' (ZICH 1986: 284). From the quote follows that this conceptual blending functions under the condition of a minimum graphic, iconic resemblance. Zich sets up elaborate rules of theatrical stylisation. Having a human body, a woman can persuasively represent a male character with greater ease as compared to a human representing a horse. The blend in Zich's terms is a difference, respectively, an overlap between a technical image and semantic image. The higher the difference, the higher the stylization. He claims that the scope of stylisation is determined by theatrical conventions and theatrical experience. 
Fig. 7: Sarah Bernhardt, Tragique historie d'Hamlet, Prince de Danemark. Poster by Alphonse Mucha, 1899. Moravian Gallery (Brno).

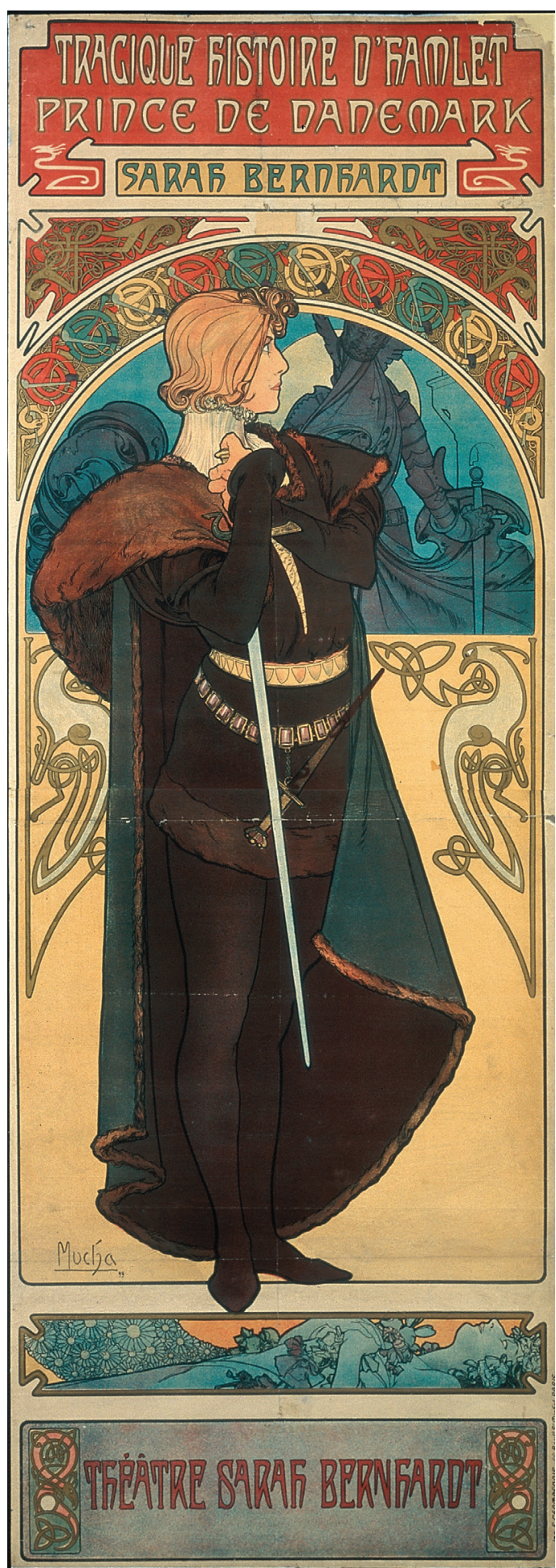




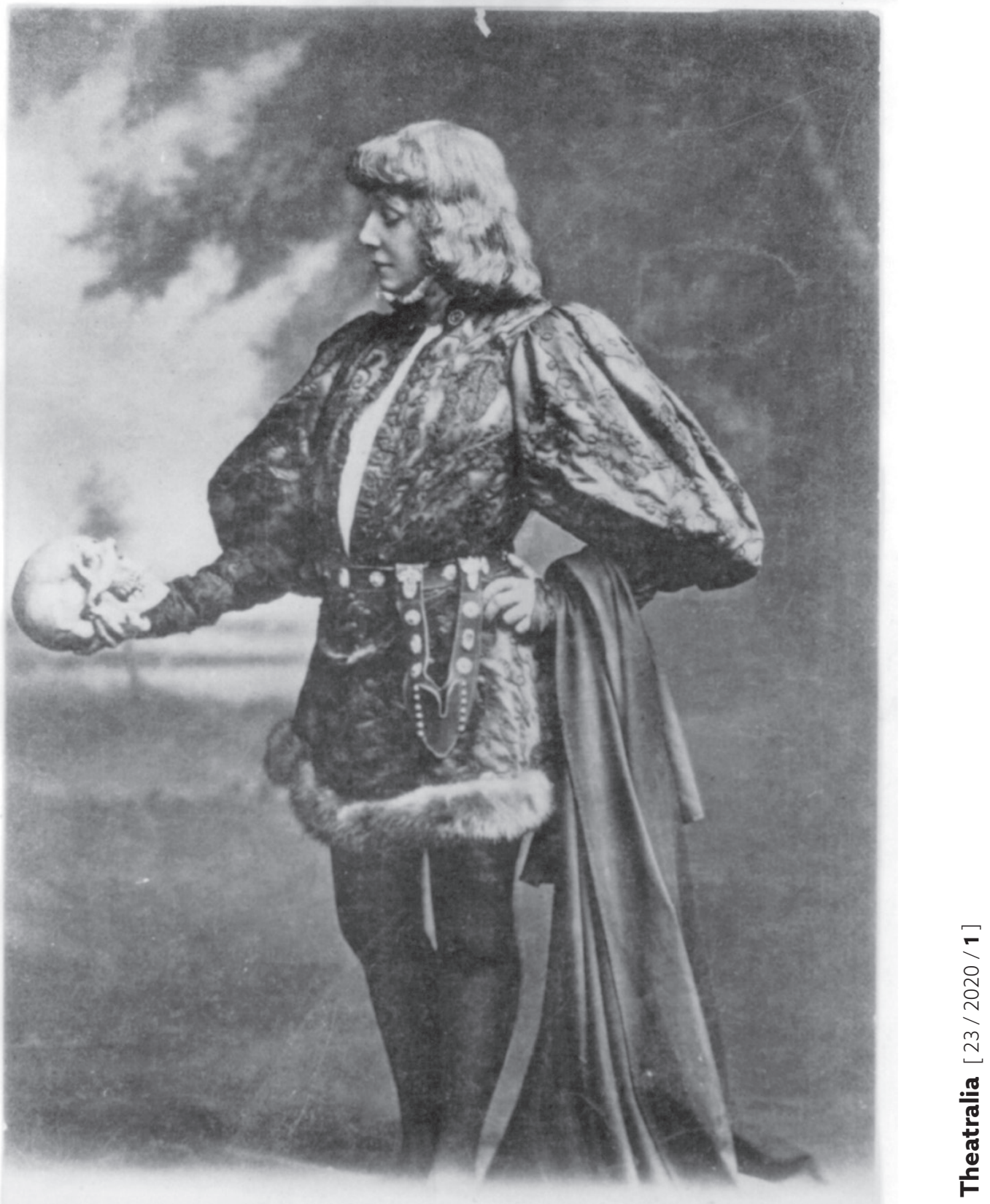

Lafaystte - Photo - London.

SARAH-BERNHARDT (HAMLET.)

Fig. 8: Sarah-Bernhardt (Hamlet.) Lafayette - photo - London.

Between 1885 and 1900. Library of Congress. 
on stage, posters, or photographs, that allowed them to show their legs in silhouette. In her Hamlet costume designed by Alphonse Mucha, Bernhardt "wears a cape and coat that drapes down to her mid-thigh - still outlines her legs, leaving little to the imagination and nothing to connect her to traditional images of older women or sagging bodies' (CORBIN 2012: 51). The title of a study by Pamela Corbin epitomizes the point: 'She's old enough to be a beautiful young boy' (CORBIN 2012). Appearing as boy enabled Bernhardt to appear as young and still desirable to counter her technical image of a fifty-five year old woman. Elizabeth Robins, a contemporaneous reviewer, testified that: 'Madame Bernhardt's assumption of masculinity is so cleverly carried out that one loses sight of Hamlet in one's admiration for the tour de force of the actress [...]' (ROBINS 1900: 908).

Does a figure on Mucha's poster represent Sarah Bernhardt the actress, a stage figure, or a dramatic character she represents? Depicted in her stage costume, the figure refers to the stage figure; she is an actress, femme fatal, though looking like a man for her admirers. Bernhardt's appearance is so radically altered that she hardly resembles herself, but does that mean that Hamlet as a dramatic persona is depicted on the poster? For George B. Shaw, Sarah Bernhardt 'does not enter into the leading character; she substitutes herself for it' (SHAW 1907: 136 in MCPHERSON 1999: 412). She herself turns into a dramatic persona not only by means of her acting and aura, but also by her stardom, 'spectacle and réclame' (MCPHERSON 1999 on her 'tour de force' (ROBINS 1900: 908)). Sarah Bernhardt here elaborates a supreme semantic image of a dramatic persona, monstre sacré or Divine Sarah, with who the other dramatic personas along with Mucha's posters or Nadar's photographs are associated, working as additional semantic imagery.

That, like Mucha, Nadar happened to be the most contemporary innovator in his favourite medium mattered less to a stare of her magnitude that her determination to orchestrate all the element of the theatrical spectacle, as if this characteristic were insufficiently evident when she renamed her theatrical company after herself. (GUNERATNE 2008: 126)

Two images are thus associated and brought together: the technical image and the representational image, i.e. the technical image of a stage figure is grouped with a representational image of a dramatic persona. Zich describes how such an amalgamation is encompassed in the presence/performance of one actor (ZICH 1986: 287). The 'transtheatrical' figure emerges on the ground of theatre performances only theoretically. Practically, every stage presentation of Bernhardt, as Hamlet, Gismonda, or Theodora proceeds from the ground of her theatrical and medial omnipresence.

Hamlet, Gismonda, or Theodora as dramatic personas were not intended to be target semantic images, but a compound of a more refined and complex work of art, technical and representational images, or performances of identity (see BUTLER 1999). According to Osolsobě, the name Bernhardt gave to her theatre exemplifies the concept of naming, just as the denomination of Equus, the God, in Shaffer's play. ${ }^{26}$

26 'Equus' stands for such a supreme representational image of a multitude of horses in the play Nugget, Trojan, Prince, etc. induced by a multitude of technical images, either graphic or non-graphic horse-actors, costumes, masks, speech, etc. 
In all the described examples, the publicity has formed an associated image of an acting actor in order to strengthen an onstage percept and an associated image of an actor (Radcliffe, Clarke, Bernhardt), along with an associated image of a persona (Alan Strang, Holly Golightly, Hamlet).

\section{Conclusion: designing a poster figure}

Theatre and posters are situated in a shared space. Nevertheless, theatre is a situated communicative situation that shows the communication of living people, with the poster a situated paper text to communicate this situation. Theatre is foremostly a presentation, a very graphic ostension of human bodies, while a poster, no matter how graphic, is foremostly a representation of dramatic personae, not a presentation of its paper materiality. The poster is situated in a relatively distinct social or economic context, and thus reflects pragmatic dramaturgical or marketing demands, in addition to putting forth semantic features.

These intermedial and semiotic translations blur the answer to the question: whom or what do we see when looking at a poster? Translating a stage figure (actor-figure) from a semiotic code of theatre to a semiotic code of a pictorial art of the poster, i.e. losing one spatial dimension, create temporal and contextual conditions that enable the poster to 'remix' the Zich's triad actor - actor-figure - dramatic persona and their related associations. ${ }^{27}$

What is seen on stage, as an actor-figure or a dramatic persona embodied as a human, is freed from the human body and staged on the poster: the stage figure turns into the poster figure. Revisiting Aristotle: 'it is perhaps impossible for people to be as beautiful as Zeuxis painted them' (ARISTOTLE 1972: 130). The poster allows separation of what merges in a single image onstage: it can divide visual and text-based associations connected to an actor from those of a dramatic persona by means of lighting, outlining, recalling, and modulating. It can alternate them and recreate them according to the media's poetic and aesthetic rules and means through montage, staged photography, abstract drawing to a mere symbolic substitution as in the case of 'Théâtre Sarah-Bernhardt' on a facade on her theatre. The more abstract the stylisation of a poster figure is, the more conceptual or symbolic meanings it renders. It thus associated with dramatic personae rather than actors, whose physical appearance can fade and disappear, in contrast to their necessary onstage presence. Both pictorial posters and theatre are representational arts (obrazové umění).

When discussing pictorial and corporeal qualities of theatre, Otakar Zich makes a small remark regarding Edward Gordon Craig, who 'considered that even an actor

27 There is a condition to which poster is subjected as well as is dramatic art: the relative and subjective resemblance between a technical and representational image is necessary for a dramatic artwork, but only in a sense of significance, i.e. in order to actually induce the desired representational image ('Relativni a subjektivni podobnost mezi prédstavou technickou a obrazovou je pro dramatické dílo nutná, ale jen ve smyslu signifikačnim, $t$. pro to, aby se žádouci obrazová představa vskutku vyvolala’) (ZICH 1986: 296). 
himself belongs to pictorial art. It is understandable that the requirement of stylization led him to the puppet' (ZICH 1986: 187). ${ }^{28}$ On a pictorial poster, the poster figure does indeed take over some properties of Craig's über-marionette: 'Art arrives only by design. Therefore, in order to make any work of art we may only work in those materials with which we can calculate. Man is not one of these materials' (CRAIG 2009).

\section{Acknowledgements}

These early-stage findings were presented at the conference Perspektivy teatrologie 3 organised by the Theatre Research Society (Czechia) in Brno on May 2019. The paper is a part of doctoral candidature at the Department of Aesthetics (Faculty of Arts, Masaryk University), under the supervision of Professor Petr Osolsobě. I also want to gratefully acknowledge comments by Tomáš Kačer, Svitlana Shurma, Daniel Sampey, and Markéta Kulhánková, as well as the courtesy of Michael Diamond and Drew Hodges, who provided the licenses for the respective images.

\section{Bibliography}

ARISTOTLE. 1972. Poetics. Transl. by T. S. Dorsch. New York: Oxford University Press, 1972.

BACHMANN-MEDICK, Doris. 2006. Cultural Turns: New Orientations in the Study of Culture. Berlin/Boston: De Gruyter, 2006.

BALME, Christopher. 1997. Interpreting the Pictorial Record: Theatre Iconography and the Referential Dilemma. Theatre Research International 22 (1997): 3: 190-201.

BRATTON, Jacky. 2003. New Readings in Theatre History. Cambridge: Cambridge University Press, 2003.

BUTLER, Judith. 1990. Gender Trouble: Feminism and the Subversion of Identity. New York: Routledge, 1990.

CARLSON, Marvin. 2010. Space and Theatre History. In Charlotte M. Canning and Thomas Postlewait (eds.). Representing the Past: Essays in Performance Historiography. Iowa: University of Iowa Press, 2010: 195-214.

CORBIN, Pamela. 2012. She's Old Enough to be a Beautiful Young Boy: Sarah Bernhardt, Breeches Roles and the Poetics of Aging. Women E Performance: a Journal of Feminist Theory 22 (2012): 1: 47-66.

CRAIG, Edward Gordon. 2009. On the Art of the Theatre. Ed. by Frank Chamberlain. New York: Routledge, 2009.

DIAMOND, Michael. 2012. Theatre Posters and How they Bring the Past to Life. Nineteenth Century Theatre and Film 39 (2012): 1: 61-76.

GUNERATNE, Anthony. 2008. Shakespeare, Film Studies, and the Visual Cultures of Modernity. New York: Palgrave Macmillan, 2008.

GOMBRICH, Ernst. 1960. Art and Illusion. A Study in the Psychology of Pictorial Representation. London: Phaidon, 1960.

28 'Anglický teoretik Craig soudil dokonce, že i herec sám patři do výttvarného uměni. Je pochopitelné, že jej pak požadavek stylizace vedl k loutce.' (ZICH 1986: 187) 
HAVLÍČKOVÁ KYSOVÁ, Šárka. 2015. Metafory, kterými žijeme: Perspektivy mezí české kognitivní teatrologie [Metaphors We Live By: Perspectives of Limits of the Czech Cognitive Theatre Studies]. Theatralia 18 (2015): 1: 65-84.

HODGES, Drew and David SEDARIS. 2016. On Broadway: From Rent to Revolution. New York: Rizzoli, 2016.

LAKOFF, George and Mark JOHNSON. 1999. Philosophy in the Flesh: The Embodied Mind and Its Challenge to Western Thought. New York: Basic Books, 1999.

LÁNSKÁ, Dita. 2016. Meaning(s) of Otakar Zich's Concept of the 'Semantic Image'. Theatralia 19 (2016): 2: 103-121.

LIDDEL, Henry, Robert SCOTT, Henry S. JONES and Roderick MCKENZIE. 1996. A Greek-English Lexicon. Oxford/New York: Clarendon Press, Oxford University Press, 1996.

METZ, Christian. 1982. The Imaginary Signifier: Psychoanalysis and the Cinema. Bloomington: Indiana University Press, 1982.

MCCONACHIE, Bruce. 2001. Doing Things with Image Schema: The Cognitive Turn in Theatre Studies and the Problem of Experience for Historians. Theatre Journal 53 (2001): 4: 569-594.

MCCONACHIE, Bruce. 2011. Engaging Audiences: A Cognitive Approach to Spectating in the Theatre. New York: Palgrave Macmillan, 2011.

MITCHELL, W. J. T. 1994. Picture Theory: Essays on Verbal and Visual Representation. Chicago: The University of Chicago Press, 1994.

MCLUHAN, Marschal. 1969. The Gutenberg Galaxy: The Making of Typographic Man. New York: New American Library, 1969.

MCPHERSON, Heather. 1999. Sarah Bernhardt: Portrait of the Actress as Spectacle. Nineteenth Century Contexts 20 (1999): 4: 409-454.

ONG, Walter J. 1982. Orality and Literacy: The Technologizing of the Word. New York: Routledge, 1982.

NOVÁK, Bohumil. 1933. Rozhovor s Otakarem Zichem [Interview with Otakar Zich]. Čin (1993): 4: 465-469.

OSOLSOBĚ, Ivo. 1981. Herecká postava pro a proti [Actor Figure For and Against]. In Jan Císař (ed.). O současné české režii 1 (= České divadlo 6). Prague: Divadelní ústav, 1981.

OSOLSOBĚ, Ivo. 1986. Two Extremes of Iconicity. In Paul Boissac, Michal Herzfeld and Roland Posner (eds.). Iconicity: Essays on the Nature of Culture. Tübingen: Stauffenburg Verlag, 1986: 95-116.

OSOLSOBĚ, Ivo. 1992. Mnoho povyku pro sémiotiku: ne zcela úspěšný pokus o encyklopedické heslo sémiotika divadla [Much Ado About Semiotics - Rather an Un-successful Attempt at an Encyclopedic Dictionary Entry 'Theatre, Semiotics of the']. Brno: Nakladatelství G, 1992.

OSOLSOBĚ, Ivo. 2007. Principia parodica totiž Posbirané papiry preváżně o divadle [Principa Parodica, or Collected Papers Mainly about Theatre]. Prague: Akademie múzických umění v Praze, 2007.

POYNOR, Rick. 2017. National Theatre Posters: A Design History. London: Unit Editions, 2017.

ROBINS, Elizabeth. 1900. On Seeing Madame Bernhardt's Hamlet by Elizabeth Robins. North American Review 171 (1900): 908-919

PROCHÁZKA, Miroslav. 1994. Komparativní sémiotika Jiřího Veltruského [Jiří Veltruský's Comparative Semiotics]. In Jiřri Veltruský. Př́spěvuky k teorii divadla [Contributions to the Theory of Theatre]. Prague: Divadelní ústav, 1994: 5-14.

RUGGIERI, Vezia et al. 2017. Psycho-Physiological Hypothesis about Visual Mental Images Projection. Academy of Social Science Journal 2 (2017): 9: 969-979. 
SCHAFFER, Peter. 1974. Equus: A Play. New York: Avon Books, 1974.

SHAW, George B. 1907. Dramatic Opinions and Essays 2. London: Archibald Constable \& Co, 1907.

SMYTH, Patricia. 2010. Beyond the Picture-Frame Stage: Late Nineteenth-Century Pictorial Theatre Posters. Nineteenth Century Theatre and Film 37 (2010): 2: 4-27.

SUS, Oleg. 1992. Geneze sémantiky hudby a básnictví v moderni české estetice (Dvě studie o Otakaru Zichovi) [Origins of the Semantics of Music and Literature in Modern Czech Aesthetics]. Brno: Filozofická fakulta Masarykovy univerzity, 1992.

THAGARD, Paul. 2005. Mind: Introduction to Cognitive Science. $2^{\text {nd }}$ ed. Cambridge: The MIT Press, 2005.

VELTRUSKÝ, Jiří. 1992. Sémiologie a avantgardní divadlo [Semiology and Anvant-garde Theatre]. Svět a divadlo 1 (1992): 145-155.

VYGOTSKY, Lev S. 1971. Psychology of Art. Cambridge, M.A.: MIT Press, 1971.

ZICH, Otakar, 1921. Estetická příprava mysli [The Aesthetic Preparation of the Mind]. Česká mysl 17 (1921): 181-204.

ZICH, Otakar. 1931. Estetika dramatického uměni [The Aesthetics of Dramatic Art]. ${ }^{\text {st }}$ ed. Prague: Melantrich, 1931.

ZICH, Otakar. 1986. Estetika dramatického umění: teoretická dramaturgie [The Aesthetics of Dramatic Art: A Theoretical Dramaturgy]. $2^{\text {nd }}$ ed. Prague: Panorama, 1986.

\section{Mgr. MgA. Martin Maryška}

Department of Aesthetics, Faculty of Arts, Masaryk University, Arna Nováka 1, 602 00, Brno, Czech Republic

m.maryska@gmail.com

Martin Maryška studied theatre management at Janáček Academy of Music and Performing Arts and aesthetics at Masaryk University. A combination of aesthetic (theater and art history) and managerial background meets his long-term interest in theatre graphic design, which he studies as a doctoral student at the Department of Aesthetics of the Faculty of Arts, Masaryk University. 
